\title{
Anatomical and radiographic study on the appendicular skeleton of the Tamandua mexicana
}

\section{Estudio anatómico y radiográfico del esqueleto apendicular de la Tamandua mexicana Estudo anatômico e radiográfico do esqueleto apendicular de Tamandua mexicana}

\author{
Ariana Calvo Varela ${ }^{1 凶}$, Mauren Hernández Valerio ${ }^{1}$, Dominique Villalobos Morales ${ }^{1}$, Alison Fernández \\ Mesén $^{1}$, Katherina Alpizar Moreno ${ }^{1}$, Dennis Salas Zamora ${ }^{1}$, Daniel Miranda Fernández ${ }^{1}$, Laura Chaverri \\ Esquivel $^{2}$, Andréia Passos Pequeno ${ }^{2}$. \\ 1 School of Veterinary Medicine, Universidad Nacional, Heredia, Costa Rica. Emails: arianasofi15@gmail.com, mauren. \\ hernandez.valerio@est.una.ac.cr, dominique.villalobos.morales@est.una.ac.cr, feralison2001@gmail.com, katherina.alpizar. \\ moreno@est.una.ac.cr, salasz.dani@gmail.com, dmirandaf96@gmail.com \\ 2 Department of Animal Anatomy, School of Veterinary Medicine, Universidad Nacional, Heredia, Costa Rica. Emails: \\ laura.chaverri.esquivel@una.cr, andreia.passos.pequeno@una.cr
}

Received: June 29, 2020. Corrected: March 26, 2021. Accepted: April 12, 2021.

\begin{abstract}
Tamandua mexicana species has an important role in the natural ecosystem as a pest controller, feeding on insects such as termites. One of the main anatomical adaptations that this species has undergone has been to its thoracic extremities. Having detailed knowledge regarding the osteology of the thoracic limbs of T. mexicana provides a strong base for its application in clinical-surgical practice. In addition to collaborating with the greater understanding of animal physiology and behavior. Because there was a lack of description about the appendicular skeleton anatomy of this species, the objective of this investigation was to describe the osteology and the radiographic anatomy of the appendicular skeleton of the T. mexicana. The bones used belonging to the appendicular skeleton of two specimens of T. mexicana were properly cleaned using standard boiling and maceration techniques. The morphometry of the bones was performed using a measuring tape, pachymeter, and radiographies. With this study, it was possible to identify and describe the anatomical peculiarities such as the presence of the double scapular spine that shapes the caudolateral fossa, and at the end of the humerus, the supratrochlear foramen, in addition to a markedly prominent medial epicondyle. In addition, a difference was observed between metacarpal bones and the phalanges of the third digit compared to the other ones, as it is significantly thicker. These findings reinforced the evidence that a certain degree of anatomical specialization is a result of an adaptation of this species to its environment and diet. The knowledge provided by research like this contributes to the improvement of surgical techniques and diagnostic approach in the species.
\end{abstract}

Keywords: Osteology, Xenarthra, appendicular skeleton, double scapular spine, supratrochlear foramen.

Autor de correspondencia: arianasofi15@gmail.com 


\begin{abstract}
Resumen
La especie Tamandua mexicana juega un papel importante en el ecosistema natural, como controlador de plagas; alimentándose de insectos como las termitas. Una de las principales adaptaciones anatómicas que ha sufrido esta especie ha sido en sus extremidades torácicas. Conocer en detalle la osteología de las extremidades torácicas de $T$. mexicana proporciona fuertes bases para su aplicación en la práctica clínico-quirúrgica. Además, de colaborar con una mejor comprensión de la fisiología y el comportamiento animal. Desafortunadamente, falta una descripción anatómica del esqueleto apendicular de esta especie. El objetivo de esta investigación fue describir la osteología y la anatomía radiográfica del esqueleto apendicular de la T. mexicana. Los huesos que pertenecen al esqueleto apendicular de los dos especímenes de T. mexicana se limpiaron adecuadamente utilizando técnicas estándar de ebullición y maceración. La morfometría de los huesos se realizó con una cinta métrica, un paquímetro y equipo radiográfico. Con este estudio fue posible identificar y describir algunas peculiaridades anatómicas como la presencia de una doble espina escapular, que forma una fosa caudolateral, y en la porción distal del húmero, la presencia de un foramen supratroclear, además de un epicóndilo medial notablemente prominente. Además, se observó una diferencia entre los metacarpianos y las falanges del tercer dedo en comparación con los otros dedos, ya que es significativamente más grueso. Estos hallazgos refuerzan la evidencia del grado de especialización anatómica como resultado de una adaptación de esta especie a su entorno y dieta. El conocimiento brindado por investigaciones como esta contribuye al mejoramiento de técnicas quirúrgicas y abordaje del diagnóstico en la especie.
\end{abstract}

Palabras clave: Osteología, Xenarthra, esqueleto apendicular, doble espina escapular, agujero supratroclear.

\begin{abstract}
Resumo
A espécie Tamandua mexicana desempenha um importante papel no ecossistema natural, especialmente como controladora de pragas; alimentando-se de insetos como cupins. As extremidades torácicas desta espécie foram um dos locais anatómicos mais susceptíveis às adaptaçóes. O conhecimento detalhado da osteologia das extremidades torácicas de T. mexicana fornece bases sólidas para sua aplicação na prática clínico-cirúrgica, além de colaborar com uma melhor compreensão da fisiologia e do comportamento animal. Infelizmente, há uma escassez de estudos com uma descrição anatômica detalhada do esqueleto apendicular desta espécie. O objetivo desta pesquisa foi descrever a osteologia e a anatomia radiográfica do esqueleto apendicular de T. mexicana. Para isso, os ossos pertencentes ao esqueleto apendicular dos dois espécimes de T. mexicana foram adequadamente limpos usando técnicas padrão de fervura e maceração. A morfometria dos ossos foi realizada com fita métrica, paquímetro e equipamento radiográfico. Com este estudo, foi possível identificar e descrever algumas peculiaridades anatômicas como a presença da dupla espinha escapular, que forma uma fossa caudolateral, e na porção distal do úmero, a presença de um forame supratroclear, além de uma epicôndilo medial marcadamente proeminente. Além disso, foi observada diferença entre os metacarpos e as falanges do terceiro dedo em relação aos demais dedos, por ser significativamente mais espesso. Esses achados reforçam as evidências do grau de especialização anatômica em decorrência da adaptação dessa espécie ao ambiente e à dieta alimentar. O conhecimento proporcionado por pesquisas como esta contribui para o aprimoramento das técnicas cirúrgicas e abordagem diagnóstica aplicadas a esta espécie.
\end{abstract}

Palavras-chave: Osteologia, Xenarthra, esqueleto apendicular, espinha escapular dupla, forame supratroclear.

\title{
Introduction
}

The anteater, Tamandua mexicana (Pilosa: Vermilingua), is distributed from the north of Mexico to the northwest regions of Peru and Venezuela (Rojano et al., 2014). This species belongs to the Myrmecophagidae family (Navarrete \& Ortega 2011; Rojano et al., 2014), which is characterized by a tubular and outstretched head, small eyes and ears; it also has a toothless oral cavity, as well as a long and slender tongue with a sticky surface (Rojano et al., 2014), this species can be easily identified by its black vest of fur (Burton \& Ceballos, 2006). 
T. mexicana is found in different habitats, that includes tropical and subtropical forests with either dry or moist conditions, they can also be present in evergreen or disturbed habitats, mangroves, secondary forest, deciduous zones, and grasslands (Superina et al., 2004). It's diet consists mainly of ants, termites (Sandoval et al., 2012), and even some fruits (Brown, 2011); due to this reason, they are considered as pest controllers. Their anatomical structure is relative to the way they hunt and consume food; these structures aid with soil removal and wood cracking to capture insects (Rojano et al., 2014), and also tree climbing to look for fruits, which they hold with one of their forepaws and break the exocarp with their two biggest claws (Brown, 2011).

Moreover, it's morphology directly relates with their ecology in order to meet some requirements such as: self-defense, for which they use their claws since their jaws are weak; coitus, during which they use their long tail and thoracic limbs for support (Rojano et al., 2014); and swimming (Esser et al., 2010). According to this information, it is important to know the appendicular skeleton (thoracic limbs and pelvic limbs) features of T. mexicana.

Therefore, the objective of this study was to describe the osteology and the radiographic anatomy of the appendicular skeleton of the T. mexicana, and in this way improve surgical approach, therefore, increase the chances of a better life quality and thus the proliferation of this species.

\section{Material and methods}

Two deceased exemplars of T. mexicana, one male (individual A) and one female (Individual B) were studied. Both specimens were provided by the Hospital de Especies Menores y Silvestres (HEMS), they received them in an injured state which required emergency medical attention. Unfortunately, they did not survive. The bodies were donated to the Anatomy laboratory of the School of Veterinary Medicine of the "Universidad Nacional de Costa Rica (UNA)", where they were used for this study.

The preparation of both individuals required the removal of the soft tissue attached to the bones, after that, the bones were boiled in a mixture of $1 \mathrm{~L}$ of water and $10 \mathrm{~g}$ of calcium oxide $(\mathrm{CaO})$ at $100^{\circ} \mathrm{C}$ for one hour. Afterwards, the osteological pieces were bleached in 3\% Hydrogen peroxide $\left(\mathrm{H}_{2} \mathrm{O}_{2}\right)$ for 24 hours and then left to dry. Morphometric measurements were taken by a single person, using the Pittsburgh Digital Caliper. The measurements were taken three times for each of the bones. Subsequently, the average of each measurement for the different bones was calculated. Table 1 explains the measurement points that were used for each of the bone measurements. The procedure used for scapular measurements was taken from Matsuo et al. (2019), for the humeral measurements was taken from Lozada-Gallegos et al. (2020) and from Aydin et al. (2017), for radial and ulnar measurements was formulated according to LozadaGallegos et al. (2020), for the femoral measurements was taken from Göker et al. (2015) and for the tibial and fibular measurements was formulated according to Liebich et al. (2020). Different standard views of the appendicular skeleton bones were photographed. Followed by radiographic photography taken for documentation using a Canon EOS 200D digital camera and the CareStream X-ray system, respectively. Radiographic technical protocols varied according to the anatomic area that is radiographed. The bones were named according to the sixth edition of the Nomina Anatomica, 2017. 
Table 1. Procedure used in the measurement of each bone.

\begin{tabular}{|c|c|c|}
\hline Bone & Measurements & Measurement points \\
\hline \multirow[t]{3}{*}{ Scapula } & Maximum length & From the dorsal border to glenoid fossa \\
\hline & Maximum width & From cranial border to caudal border \\
\hline & Minimum width & Diameter of the scapula neck \\
\hline \multirow[t]{3}{*}{ Humerus } & Maximum Length & From the head of the humerus to the trochlea \\
\hline & Vertical head diameter & From the cranial to the caudal portion of the head of the humerus \\
\hline & Maximum width of distal epiphysis & From medial epicondyle to lateral epicondyle \\
\hline \multirow[t]{3}{*}{ Radius } & Maximum Length & From the head of the radius to the medial styloid process \\
\hline & Maximum proximal width & Head width \\
\hline & Maximum distal width & From the distal articular facet to radius to the medial styloid process \\
\hline \multirow[t]{3}{*}{ Ulna } & Maximum Length & From the olecranon tubercle to the ulna styloid process \\
\hline & Maximum width of articular surface & From the trochlear incisure to the medial coronoid process \\
\hline & $\begin{array}{l}\text { Length of the olecranon from the } \\
\text { anconeus process to the apex }\end{array}$ & From the anconeus process to the olecranon tubercle \\
\hline \multirow[t]{3}{*}{ Femur } & Length from head & From the head of the femur to the epicondyles \\
\hline & Vertical head diameter & From the medial to the lateral portion of the head of the femur \\
\hline & Intercondylar fossa width & Space between medial epicondyle and lateral epicondyle \\
\hline \multirow[t]{3}{*}{ Tibia } & Maximum Length & From the intercondylar eminence to the cochlea of the tibia \\
\hline & Maximum proximal width & From the medial condyle to the lateral condyle \\
\hline & Maximum distal width & From the medial malleolus to the distal articular face with fibula \\
\hline \multirow[t]{3}{*}{ Fibula } & Maximum Length & From the head of the fibula to the lateral malleolus \\
\hline & Maximum proximal width & Width of the proximal portion of the bone \\
\hline & Maximum distal width & Width of the distal portion of the bone \\
\hline
\end{tabular}

\section{Results}

\section{Anatomic description of the Thoracic limb}

\section{Scapula}

During this study, several peculiar characteristics of the bone structure of this species were identified. Some of these particularities were found on the scapula (Figure 1), which not only had the scapular spine with an acromion in its distal portion, but also, a secondary one named accessory scapular spine that gives rise to a caudolateral fossa. This bone structure has an acromion process which goes upwards and extends past the shoulder joint. 


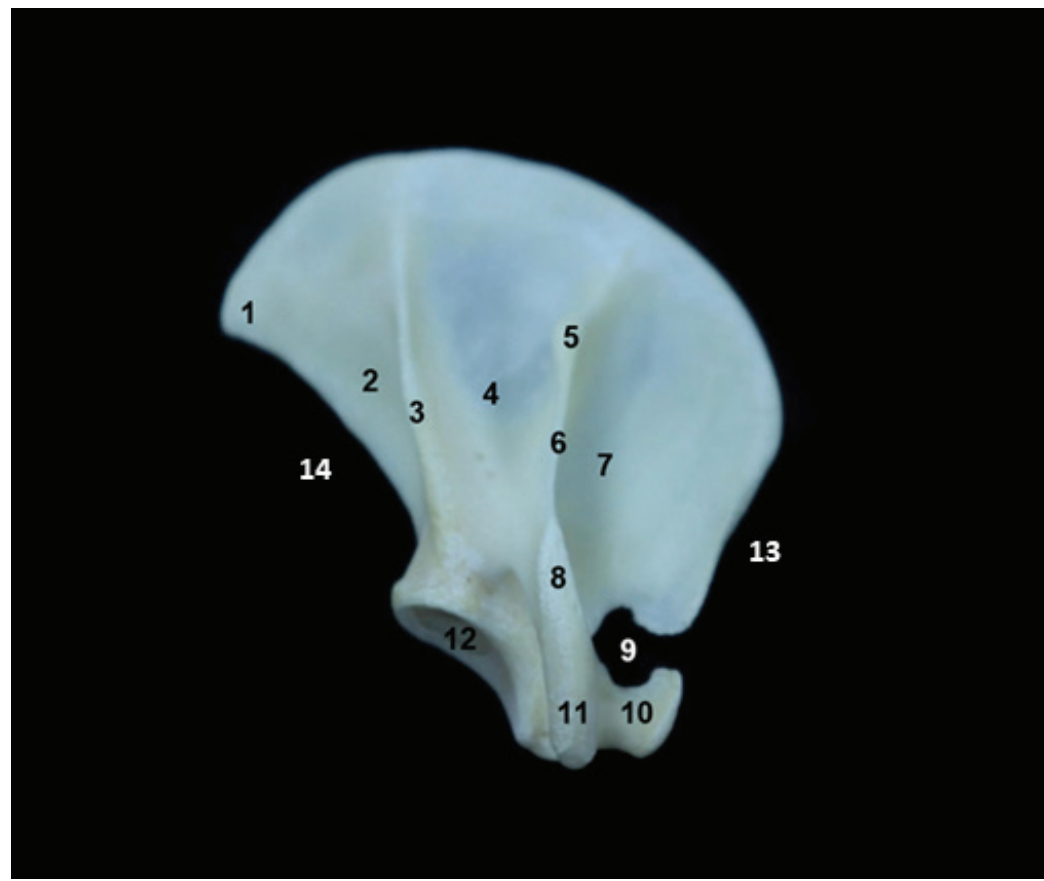

Figure 1. Structures of the T. mexicana right scapula. Lateral view: 1 - caudal border, 2 - caudolateral fossa, 3 - accessory scapular spine, 4 - infraspinous fossa, 5 scapular spine tuberosity, 6 - scapular spine, 7 - supraspinous fossa, 8 - acromion, 9 - supraglenoid notch, 10 - supraglenoid tubercle, 11 - hamate process, 12 - glenoid fossa, 13 - cranial border, 14 - caudal border. Photograph by the authors.

Morphometric measurements obtained for the scapula showed that the difference between the right and left bone in each anteater is of $0.12 \mathrm{~mm}$, which makes it insignificant (Table 2). For example, in the case of the measurements of maximum length, for individual A differ by $0.7 \mathrm{~mm}$ and for individual B by $1.46 \mathrm{~mm}$, but when comparing between specimens the discrepancy is evident, since the difference of the right scapula of both individuals is of $21.95 \mathrm{~mm}$ and for the left ones is of $21.19 \mathrm{~mm}$.

Table 2. Scapula measurements

\begin{tabular}{llcc}
\hline Measurement & Laterality & Individual A (mm) & Individual B (mm) \\
\hline Maximum length & Right & 57.39 & 40.88 \\
& Left & 57.27 & 40.56 \\
Maximum width & Right & 61,74 & 49,30 \\
& Left & 60.08 & 49.66 \\
Minimum width & Right & 18.83 & 16,56 \\
& Left & 18,58 & 16.27 \\
\hline
\end{tabular}




\section{Humerus}

For the humerus (Figure 2), it was possible to identify a craniocaudal flattened distal portion with a prominent medial epicondyle, a supratrochlear foramen, and a notorious deltoid tuberosity that faces laterally.

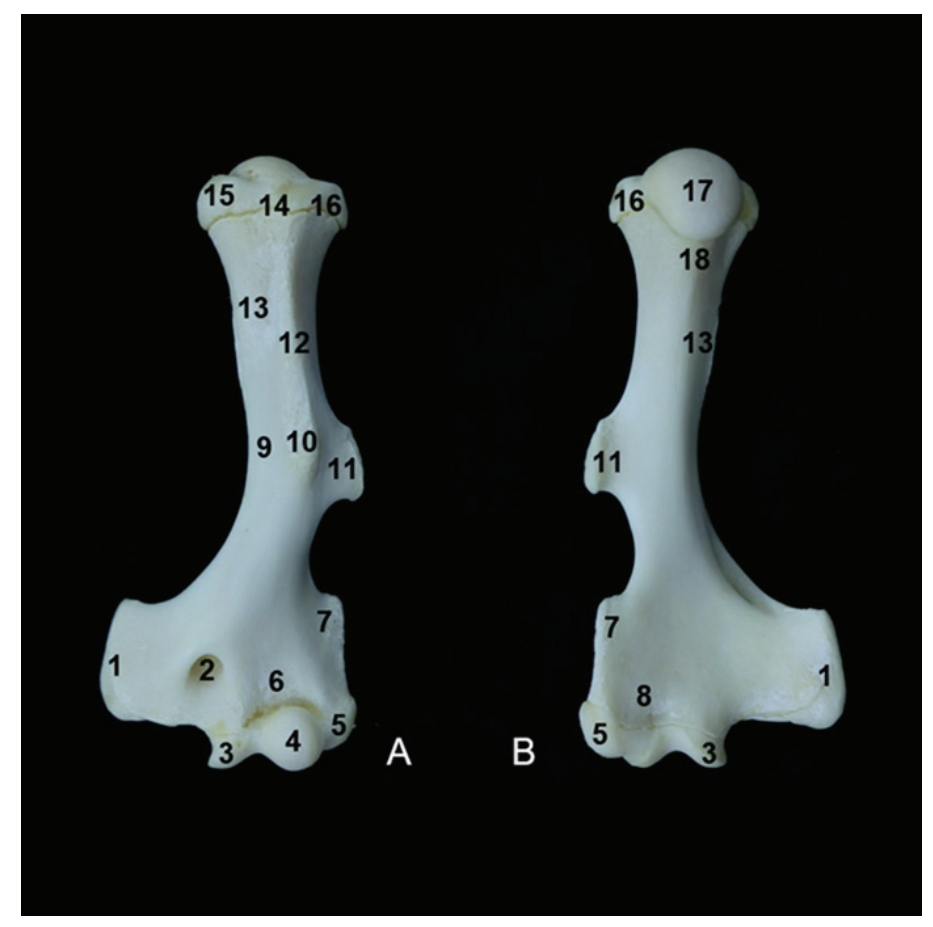

Figure 2. Structures of the T. mexicana left humerus. A: Craneal view. B: Caudal view: 1 - medial epicondyle, 2 - supratrochlear foramen, 3 - trochlea, 4 - capitulum, 5 - lateral epicondyle, 6 - radial fossa, 7 - supracondylar ridge, 8 - olecranon fossa, 9 - humeral body, 10 - pectoral tuberosity, 11 - deltoid tuberosity, 12 - pectoral ridge, 13 tuberosity of the teres major muscle, 14 - intertubercular groove, 15 - lesser tubercle, 16 - greater tubercle, 17 humeral head, 18 - humeral neck.

Photograph by the authors.

There was a slight difference between right and left humerus measurements in each specimen, nevertheless, there is a greater inequality comparing the humerus of the individuals involved (Table 3). For instance, both humeri of individual A differ by $0.33 \mathrm{~mm}$ of maximum length, and for individual B by $1.84 \mathrm{~mm}$. On the other hand, the right humerus of individuals A and B have a difference of $17.35 \mathrm{~mm}$ and the left ones of $15.84 \mathrm{~mm}$.

Table 3. Humerus measurements

\begin{tabular}{llcc}
\hline Measurement & Laterality & Individual A (mm) & Individual B (mm) \\
\hline Maximum Length & Right & 91.4 & 73.04 \\
& Left & 91.2 & 73.63 \\
Vertical head diameter & Right & 16,70 & 14.22 \\
& Left & 16,42 & 14.69 \\
Maximum width of distal epiphysis & Right & 38,47 & 32.44 \\
& Left & 38,58 & 32.46 \\
\hline
\end{tabular}


Figure 3. Structures of the T. mexicana left radius. A: Cranial view. B: Medial view. 1 - radial head, 2 - radial neck, 3 - proximal articular facet to the ulna, 4 - bicipital tubercle, 5 - diaphysis, 6 - lateral radial crest, 7 - medial styloid process, 8 - trochlea, ${ }^{*}$ - physis.

Photograph by the authors.

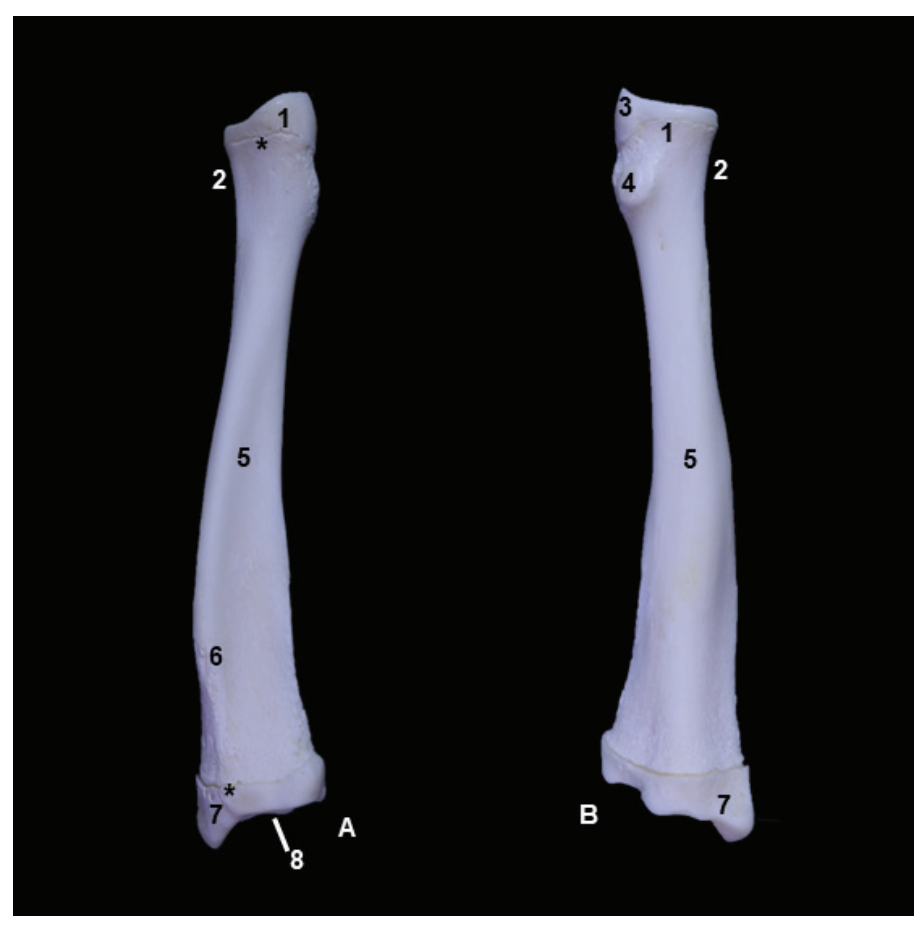

\section{Radius}

This bone presents a difference in width between the proximal end and the distal end; the distal portion widens and lengthens through the radial styloid process, and appears to be slightly flattened (Figure 3). In its proximal end are the head and neck of the radius, as well as the radial fossa, also noticeable is an incurvature along the body of the radius. At its distal portion, the radial trochlea and the articular face for the carpus are identifiable.

Table 4. Radius measurements

\begin{tabular}{llcc}
\hline Measurement & Laterality & Individual A (mm) & Individual B (mm) \\
\hline Maximum Length & Right & 76.42 & 61.74 \\
& Left & - & 61.58 \\
Maximum proximal width & Right & 11.09 & 9,17 \\
& Left & - & 9,24 \\
Maximum distal width & Right & 18.28 & 15,56 \\
& Left & - & 15.59 \\
\hline
\end{tabular}

Due to a fracture in the right thoracic limb of individual $\mathrm{A}$, measurements of the radius could not be taken (Table 4). For the left bone, a representative difference of maximum length of $13.48 \mathrm{~mm}$ was found between both individuals. 


\section{Ulna}

Regarding the ulna (Figure 4), it is fully developed. The bone presents a ventrolateral flattening, at its proximal portion it is possible to identify the olecranon and the trochlear notch which articulates it with the radius. It was also possible to recognize the styloid process at its distal portion.

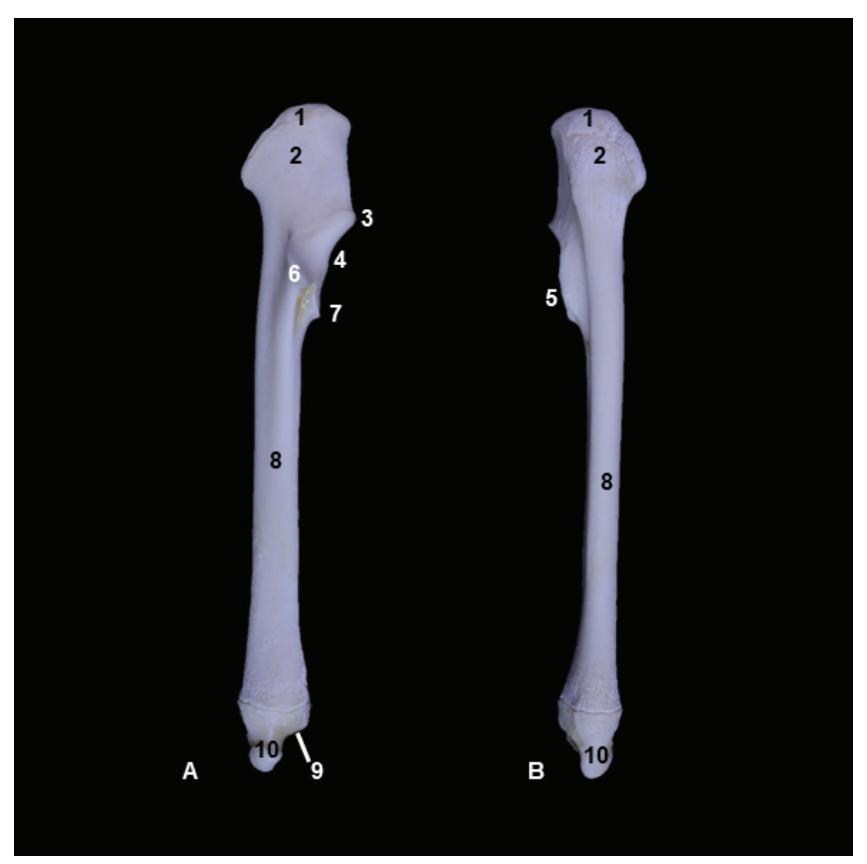

Figura 4. Structure of the T. mexicana right ulna. A: Lateral view. B: Caudal view. 1 - olecranon tubercle, 2 - olecranon, 3 anconeus process, 4 - trochlear incisure, 5 - medial coronoid process, 6 - lateral coronoid process, 7 - proximal articular facet to radius, 8 - diaphysis, 9 - distal articular facet to radius, 10 - ulna styloid process. Photograph by the authors.

Table 5. Ulna measurements

\begin{tabular}{llcc}
\hline Measurement & Laterality & Individual A (mm) & Individual B (mm) \\
\hline Maximum Length & Right & 98.46 & 77.98 \\
& Left & - & 77.75 \\
Maximum width of articular surface & Right & 12.42 & 10.11 \\
& Left & - & 10.36 \\
Length of the olecranon from the anconeus process to the apex & Right & 18.79 & 14,84 \\
& Left & - & 14.84 \\
\hline
\end{tabular}

Source: Own elaboration.

8 
Due to a fracture in the right thoracic limb of individual A, measurements of the ulna could not be taken.

Regarding the ulna, it was impossible to make a comparison between the right and left ulna of individual A, since one of them was fractured (Table 5). According to the maximum length measurement in individual B, a difference of $0.21 \mathrm{~mm}$ is observed between the right and left ulna. Between individuals $\mathrm{A}$ and $\mathrm{B}$, taking in consideration the measures of the left ulna, there is a difference of $19.85 \mathrm{~mm}$.

\section{Carpal, metacarpal bones, and phalanges}

The carpal bones (Figure 5) are conformed by eight bone structures positioned in two different rows, a proximal and a distal one. The proximal row consists of the carporadial bone, the intermedius carpal bone, the ulnar carpal bone, and the accessory carpal bone; there is also the presence of a sesamoid bone. The distal row has four bones that include the first, second, third and fourth carpal bones.

The metacarpal bones are rather thin, except for the third digit, which is very prominent and solid. Most of them have three phalanges, which are classified as proximal, middle, and distal, except for the first and fifth digit; the first one doesn't have a middle phalange and the fifth digit lacks the proximal phalanges and the claw. Therefore, the latter cannot be seen externally. The sizes of the third digit phalanges are not consistent with the rest of the digits, as the proximal phalanx is smaller than the distal one; its claw is the biggest one of them all (Figure 5).

Figure 5. Left carpal, metacarpal bones and phalanges of $T$. mexicana thoracic limb. 1- carpal bones, 2 - metacarpal bones, 3 - proximal phalanx, 4 - middle phalanx, 5 - distal phalanx, I - first digit, II - second digit, III - third digit, IV - fourth digit, $\mathrm{V}$ - fifth digit, ${ }^{*}$ - sesamoid bone. Photograph by the authors.

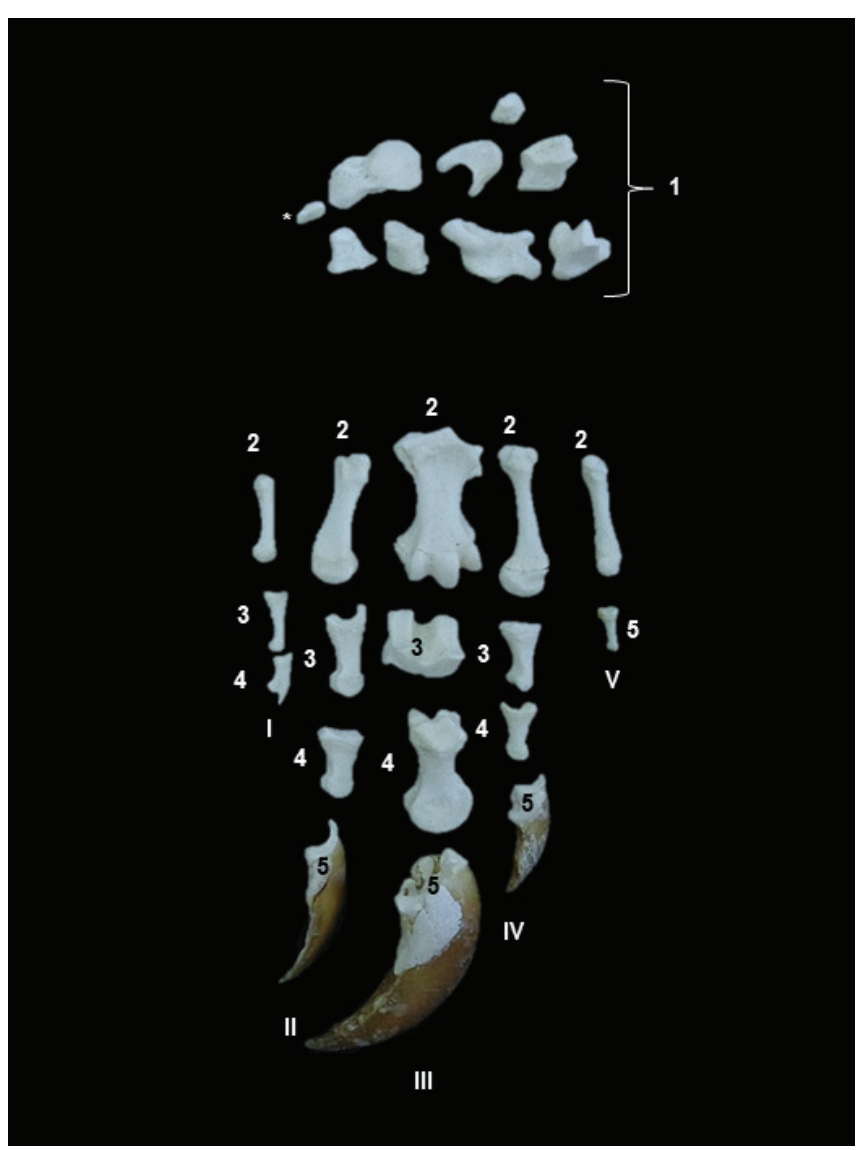




\section{Anatomic description of Pelvic limb}

\section{Femur}

The femur has a prominent femoral head, and distal from this structure is the greater trochanter, which is separated from a lesser trochanter that faces medially. There is also a visual asymmetry between the epicondyles, which is present at the distal epiphysis; the medial one is larger and rounder than the lateral, since the latter is flattened on its outer border. On this distal portion of the bone, a patellar groove can be seen, however, it is very shallow and broad. There is a small subtle hollowed section in the dorsomedial portion of the femoral head, which is known as the fovea capitis (Figure 6).

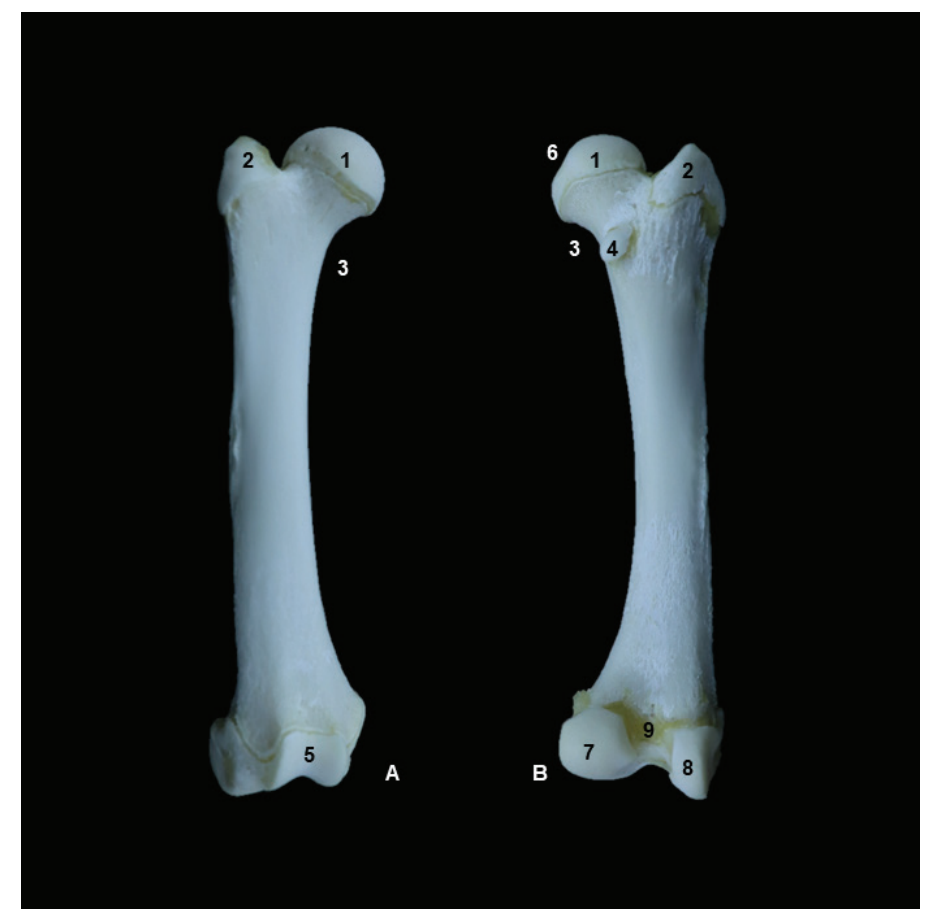

Figure 6. Structures of the T. mexicana right femur. A: Cranial view: B: Caudal view. 1 - femoral head, 2 - greater trochanter, 3 femoral neck, 4 - lesser trochanter, 5 - patellar groove, 6 - fovea capitis, 7 - medial epicondyle, 8 - lateral epicondyle, 9 - popliteal face. Photograph by the authors.

Table 6 shows the measurements obtained for comparing between the left and right bone of each specimen and also for the comparing between both. Anteater 1 remained as the animal with the largest bones and the differences between right and left bone were less than $1.0 \mathrm{~mm}$ in each animal. An example of this difference is seen in the case of the measurements of length from head of the individual $\mathrm{A}$, which differs by $0.03 \mathrm{~mm}$, and for individual $\mathrm{B}$, which differs by $0.06 \mathrm{~mm}$. However, when comparing the specimens, the discrepancy is evident, especially within the difference between the right femur of both individuals, which is $17.34 \mathrm{~mm}$, and for the left, which is of $17.37 \mathrm{~mm}$. 
Table 6. Femur measurements

\begin{tabular}{llcc}
\hline Measurements & Laterality & Individual A $(\mathrm{mm})$ & Individual B (mm) \\
\hline Length from head & Right & 89.33 & 72.37 \\
& Left & 91.38 & 72.64 \\
Anteroposterior diameter of the head & Right & 13.92 & 11.72 \\
& Left & 14.29 & 11.86 \\
Intercondylar fossa width & Right & 4,53 & 6.7 \\
& Left & 4.63 & 6.36 \\
\hline
\end{tabular}

\section{Tibia}

This bone has two epiphyses (proximal and distal), the osseous structure that lays between them is called the diaphysis. The proximal epiphysis is wider than the distal. This larger bone contains a tibial tuberosity, which is subtle, making the tibial ridge unnoticeable, unlike in domestic mammals such as the Canis lupus familiaris species in which this structure is very prominent, as stated by Liebich et al. (2020). This means that the difference in this species is the absence of the tibial ridge. Also, the diaphysis of this bone structure is somewhat bent (Figure 7).

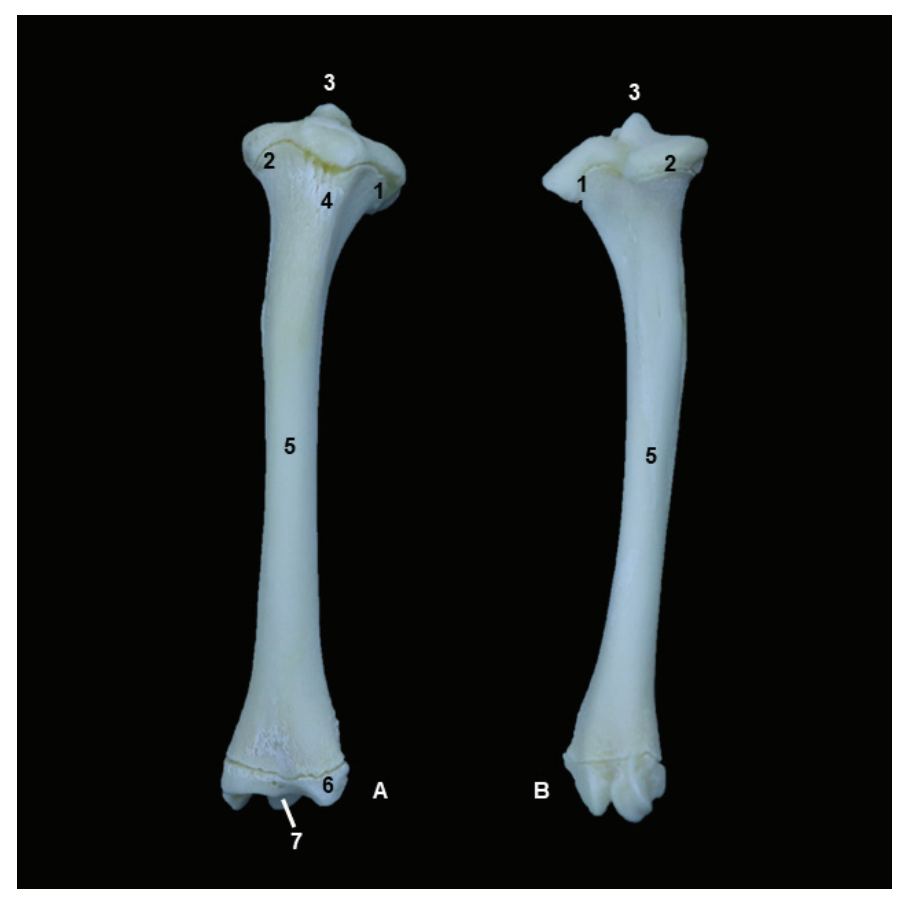

Figure 7. Structures of the T. mexicana right tibia. A: Craneal view. B: Caudal view. 1 - medial condyle, 2 - lateral condyle, 3 - intercondylar eminence, 4 - tibial tuberosity, 5 - diaphysis, 6 medial malleolus, 7 - cochlea. Photograph by the authors. 
Table 7. Tibial measurements

\begin{tabular}{llcc}
\hline Measurement & Laterality & Individual A $(\mathrm{mm})$ & Individual B (mm) \\
\hline Maximum Length & Right & 90.52 & 70.41 \\
& Left & 89.22 & 70.17 \\
Maximum proximal width & Right & 20,78 & 18,20 \\
& Left & 20.80 & 18.27 \\
\multirow{3}{*}{ Maximum distal width } & Right & 17.44 & 16.91 \\
& Left & 17.52 & 16.88 \\
\hline
\end{tabular}

Measurements obtained for the tibia indicate that between both limbs, the difference is very small, but between individuals, the difference is more noticeable (Table 7). The difference between the maximum length of the right and left tibia in individual $\mathrm{A}$ was $1.31 \mathrm{~mm}$, but in individual $\mathrm{B}$, the difference was $0.32 \mathrm{~mm}$.

\section{Fibula}

It is a straight structure that contains one facet that allows a close articulation with the tibia. Its proximal epiphysis is narrower than the distal one, which is wider and rather flat (Figure 8).

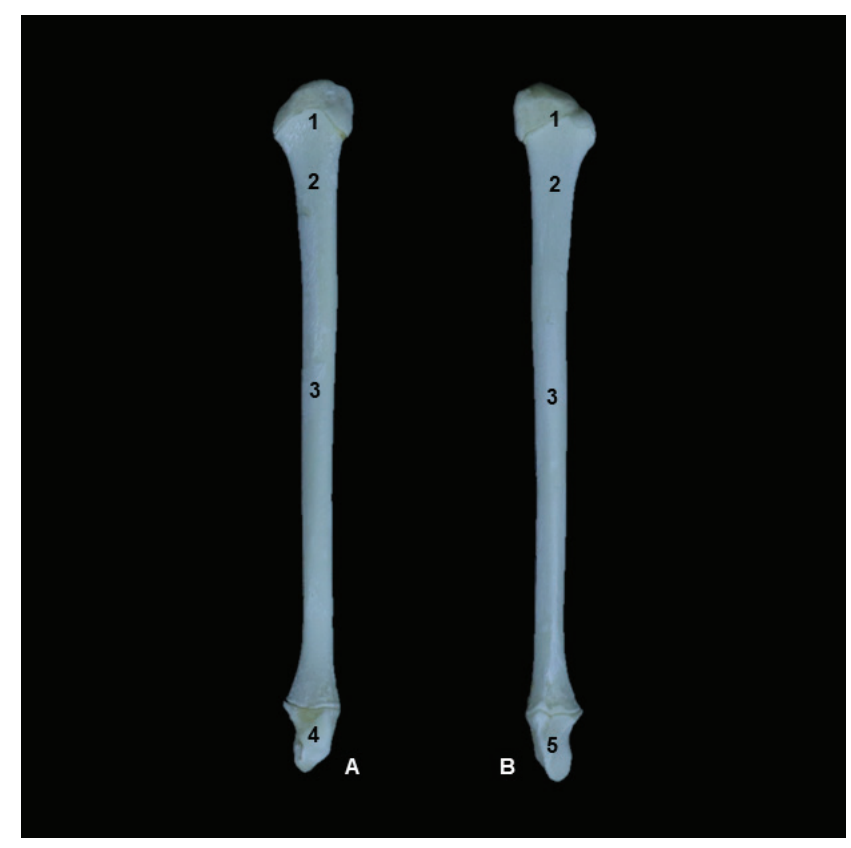

Figure 8. Structures of the T. mexicana right fibula. A: Lateral view. B: Medial view. 1 - fibular head, 2 - fibular neck, 3 - diaphysis, 4 - lateral malleolus, 5 - distal articular facet to tibia. Photograph by the authors. 
Table 8. Fibula bone measurements

\begin{tabular}{llcc}
\hline Measurement & Laterality & Individual A $(\mathrm{mm})$ & Individual B $(\mathrm{mm})$ \\
\hline Maximum Length & Right & 80,58 & 62.03 \\
& Left & 80.53 & 62.08 \\
Maximum proximal width & Right & 9.54 & 7.52 \\
& Left & 9.64 & 7.65 \\
\multirow{2}{*}{ Maximum distal width } & Right & 6.66 & 5.89 \\
& Left & 6.49 & 5.86 \\
\hline
\end{tabular}

Regarding the maximum length of the fibula, according to the measurements obtained, it is determined that it maintains the same pattern as the other bones, since the difference between the left and right bone is almost imperceptible, however, between specimens, a noticeable difference is observed (Table 8). Regarding maximum length measurements, specimen A differs by $0.06 \mathrm{~mm}$ and specimen $\mathrm{B}$ by $0.04 \mathrm{~mm}$. When comparing between individuals the discrepancy is evident because the dissimilarity of the right fibula of both individuals is of $17.45 \mathrm{~mm}$, and for the left ones is of $17.47 \mathrm{~mm}$.

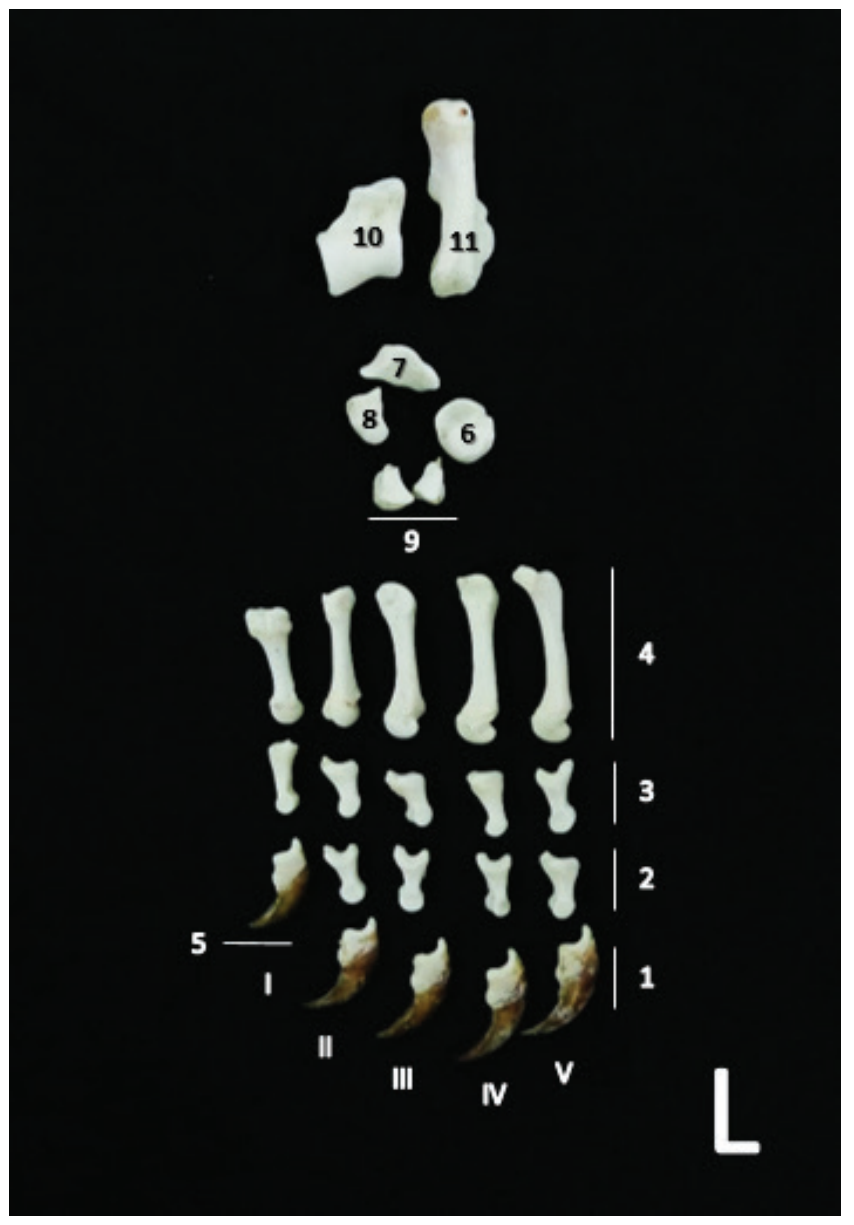

Figure 9. T. mexicana left pes. 1 - distal phalanges of first, second, third and fourth digits, 2 - medial phalanges of first, second, third and fourth digits, 3 - proximal phalanges of first, second, third, fourth and fifth digits, 4 - metatarsal bones, 5 - distal phalanx of the fifth digit , 6 - central tarsal bone, 7 - first tarsal bone, 8 - fourth tarsal bone, 9 - second and third tarsal bones, 10 - talus, 11 - calcaneus. Photograph by the authors. 


\section{Tarsal, metatarsal bones, and phalanges}

The identity of each one of these bones cannot be guaranteed due to the lack of information available about the T. mexicana appendicular skeleton, nevertheless, the following anatomical interpretation highly suggests the possible identification of said structures. The description that will be carried is based on the anatomic comparison of this species and domestic animals such as the $C$. familiaris, which will be later discussed.

The tarsal bones (Figure 9) consist of three different rows (proximal, medial and distal) conformed by different shaped bones which articulate between themselves and other structures such as the tibia and fibula. The proximal row is established by the calcaneus and talus bones, the first one mentioned has an elongated body and, at its most caudal edge, the calcaneal tuber is present, which can be manually perceived. The talus bone has a smooth, roundly shaped trochlea with two well-defined ridges at the surface that lay parallely to each other. This bone also has a body, which conforms the distal portion of the talus, that articulates with the central tarsal bone. The talus also articulates proximally with the tibial distal epiphysis and laterally with the calcaneus bone. The central tarsal bone is the only structure that constitutes the medial tarsal row, it peripherally articulates with the tarsal bones that integrate the distal row, these being the first, second, third and fourth tarsal bones. The second and third tarsal bones are seen as one predominantly flat structure but aren't fused. Both proximally articulate with the central tarsal bone.

The T. mexicana species has five digits (Figure 9), every metatarsal bone is rather thin and distally articulates with the proximal phalanges. The distal epiphysis of the latter articulates with the proximal portion of the middle phalanges that distally articulates with the proximal epiphysis of the distal phalanges. Except for the fifth digit that only has two phalanges, the four remaining digits have three phalanges each.

\section{Radiographic description of the appendicular skeleton}

\section{Thoracic Limb}

Due to this radiography (Figure 10), the T. mexicana's thoracic limb articular disposition can be appreciated. The scapular caudal angle and caudal border appear to be radiopaque, while the subscapular fossa and the coracoid process have a radiolucent conformation. In the middle of the scapula, a thin white line is seen, this is the scapular spine which is highly radiopaque. The humeral head articulates with the glenoid cavity, both seem radiolucent, however, while the humeral head is round-shaped, the glenoid cavity is concave. Across the humeral head, there is a thick, radiopaque, elongated, and narrow structure; this is called the hamatus process of the acromion. At the proximal epiphysis of the humerus, two structures are distinguishable, cranial to the humeral head: the lesser tubercle and the greater tubercle, both of which have a radiolucent appearance. The humeral diaphysis, though mostly radiolucent, also has a very radiopaque structure that can be identified as the pectoral tuberosity, which overlaps the deltoid tuberosity. On the humeral distal epiphysis, a prominent radiolucent structure is seen, this is the medial epicondyle, followed by the radial fossa and then the humeral capitulum, which resemble a radiolucent round-shaped prominence. The radius articulates with the humeral capitulum by the radial articular fossa, while the ulna articulates to the humerus by the trochlear notch. The positioning of the anconeal process on the radial fossa and the olecranon over the humeral medial epicondyle provides these structures with a radiolucent appearance. The ulna articulates with the radius on the radial notch, both bones have a radiolucent diaphysis with radiopaque borders. 


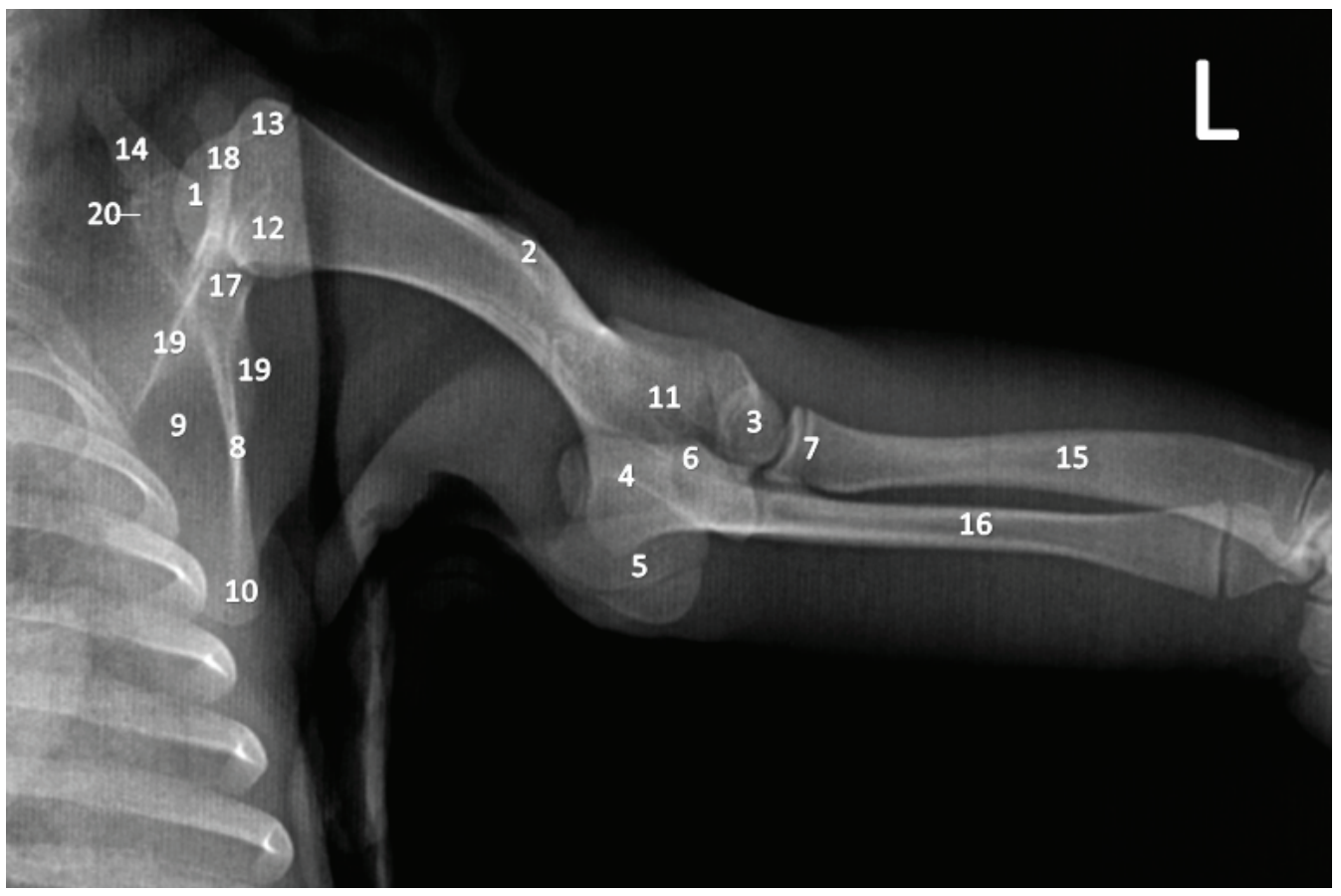

Figure 10. Radiographic view of the left thoracic limb of the T. mexicana. Mediolateral view: 1 - humeral head, 2 - pectoral tuberosity, 3 - capitulum. 4 - olecranon, 5 - medial epicondyle, 6 - anconeal process, 7 - radial articular surface, 8 - scapular caudal border, 9 - subscapular fossa, 10 - caudal scapular angle, 11 - radial fossa, 12 - lesser tubercle, 13 - greater tubercle, 14 - coracoid process, 15 - radial diaphysis, 16 - ulnar diaphysis, 17 - glenoid cavity, 18 - hamatus process of the acromion, 19 - scapular spine, 20 - suprascapular nerve foramen. Photograph by the authors.

Regarding the carpal bones, (Figure 11) the radiographic shows that the proximal portion of the proximal row is convexly shaped and its bones are mostly radiopaque. It also details the articulation of the proximal portions of both the carporadial bone and the intermedius carpal bone with the radius. The ulnar carpal bone articulates proximally with the ulna and the accessory carpal bone articulates only with the ulnar carpal bone. Also, the sesamoid bone can be found near the radial carpal bone. The first, second and third carpal bones conform part of the distal carpal row along with the fourth carpal bone. The first three carpal bones mentioned, distally articulate with their respective metacarpal bones, while the fourth carpal bone articulates at its distal portion with the third, fourth and fifth metacarpal bones. All the distal carpal bones are more radiolucent than the proximal carpal bones. It can also be observed that the accessory carpal bone overlaps the ulnar carpal bone.

Regarding the joints, when observed from a dorsopalmar view, the metacarpophalangeal joint is present in the totality of the digits, while the proximal interphalangeus joint can only be seen on the second, third and fourth digits, and the distal interphalangeus joint is present on the first four digits. Additionally, both epiphysis and the outline of the metacarpal bones have a radiopaque appearance, but the more centric portion of the diaphysis is seen as a radiolucent structure, the same for the majority of the phalanges except the third proximal phalanx that is complete radiopaque. 
Figure 11. Left carpal and metacarpal bones and phalanges of the T. mexicana. Dorsopalmar view from individual 2. 1Radial carpal bone, 2 - intermedius carpal bone, 3 - ulnar carpal bone, 4 - accessory carpal bone, 5 - sesamoid bone, 6 - first carpal bone, 7 - second carpal bone, 8 - third carpal bone, 9 - fourth carpal bone, 10 - metacarpal bones, 11- proximal phalanx, 12-middle phalanx, 13-distal phalanx, I - first digit, II second digit, III - third digit, IV - fourth digit, V - fifth digit. Photograph by the authors.

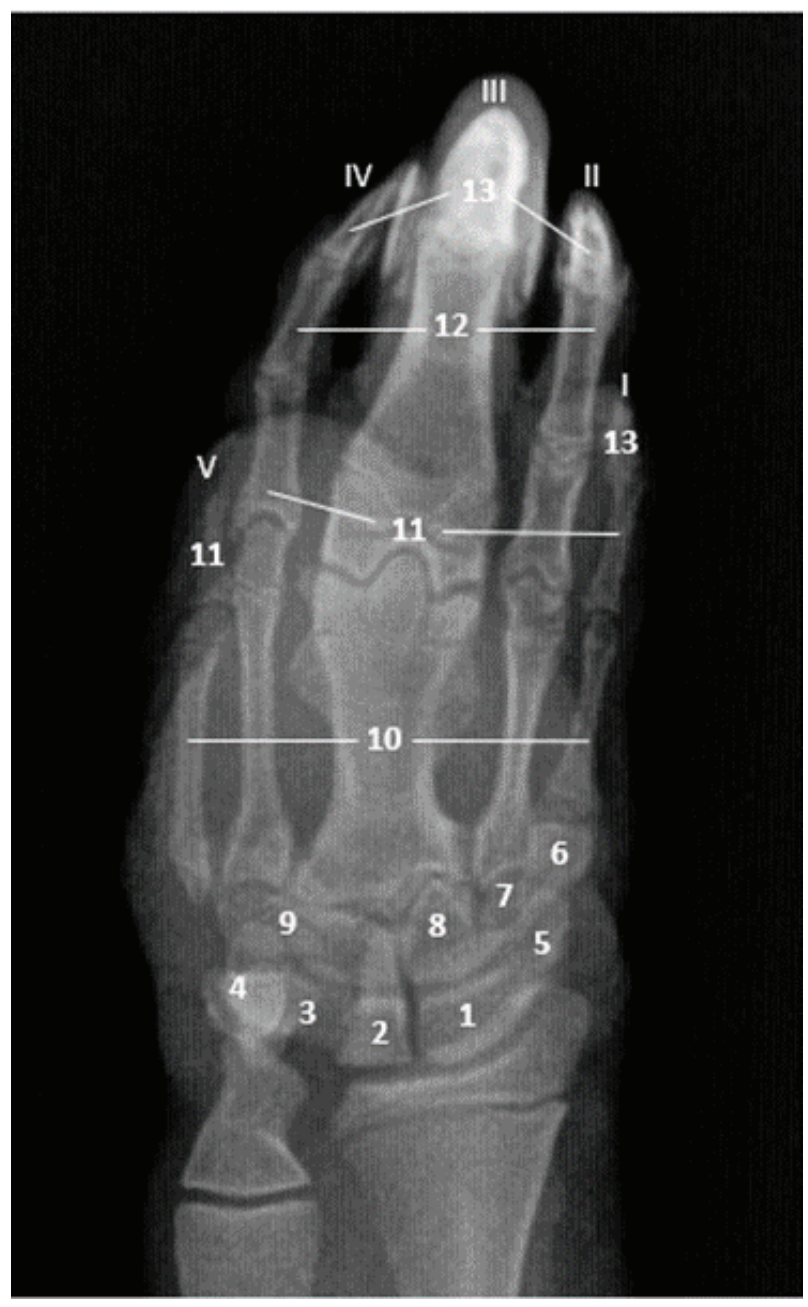

\section{Pelvic Limb}

Regarding the radiograph of the pelvic limb (Figure 12), it appears that the femur is a long bone, its diaphysis is almost all radiolucent except for its lateral border which is subtly radiopaque. This bone also has a femoral head, which is a radiolucent round eminence and is articulated to the acetabular cavity from the coxal bone, which is radiolucent and concave. Next to the femoral head, is a greater trochanter, which is a well-defined structure that is mostly radiolucent but with a radiopaque outline. On the femoral distal epiphysis, the trochlea can be seen as a radiopaque structure. This is also where the patella is found; it is seen as a more radiolucent bone positioned onto the patellar groove, and present on the previously mentioned trochlea. The tibia, a long bone that has a radiolucent body with a radiopaque outline, articulates with the femur at the level of medial and lateral condyles (both radiopaque). It is seen with the intercondylar eminence and has a radiolucent appearance if viewed from a cranial view. On the proximal portion of the tibia, the tibial tuberosity can be found as a more radiolucent, slightly prominent structure. Next to the inferior articular surface of the tibia distal epiphysis, is the medial malleolus, a radiolucent bone. The fibula articulates with 
the tibia on an oblique position, its diaphysis is very radiopaque while its proximal portion, the fibular head, and its distal portion, named lateral malleolus, are both radiolucent.

As previously stated, the calcaneus (a mostly radiopaque tarsal bone) (Figure 13) articulates with the radial inferior articular surface, which is a concave radiolucent structure. The calcaneus has a caudally elongated portion known as the calcaneal tuber; this structure is overlapped by the medial malleolus. This bone cranially articulates with the central tarsal bone (radiopaque); that also articulates laterally with the first tarsal bone, which has a radiolucent appearance. These two structures are cranially followed by the radiolucent metacarpal bones, which cranially articulate with the proximal, medial, and distal phalanges that are also radiolucent. The talus has mostly a radiolucent body with radiopaque edges. Its proximal portion has a rounded shape to it that articulates with the distal epiphysis of the tibia, while the distal one seems like a narrower and straighter end that distally articulates with the proximal portion of the central tarsal bone.

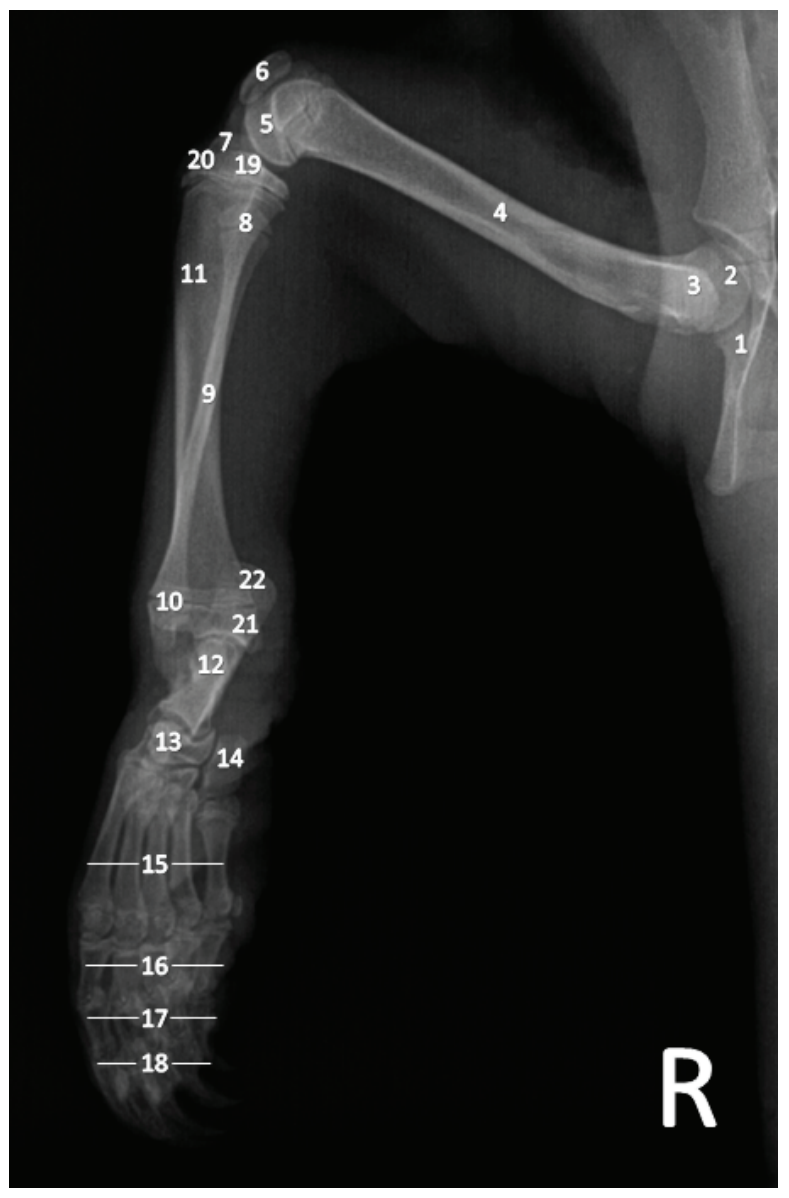

Figure 12. Radiographic view of the right pelvic limb of the $T$. mexicana. Mediolateral view: 1 - acetabular cavity, 2 - femoral head, 3 - Greater trochanter, 4 - femoral diaphysis, 5 - Trochlea (with patellar groove), 6 - Patella, 7 - intercondylar eminence, 8 fibular head, 9 - fibular diaphysis, 10 - Lateral malleolus, 11 - tibial diaphysis, 12 - calcaneus, 13 - central tarsal bone, 14 - first tarsal bone, 15 - metacarpal bones, 16 - proximal phalanges, 17 - medial phalanges, 18 - distal phalanges, 19 - medial condyle, 20 - tibial tuberosity, 21 - medial malleolus, 22 - calcaneal tuber. Photograph by the authors. 


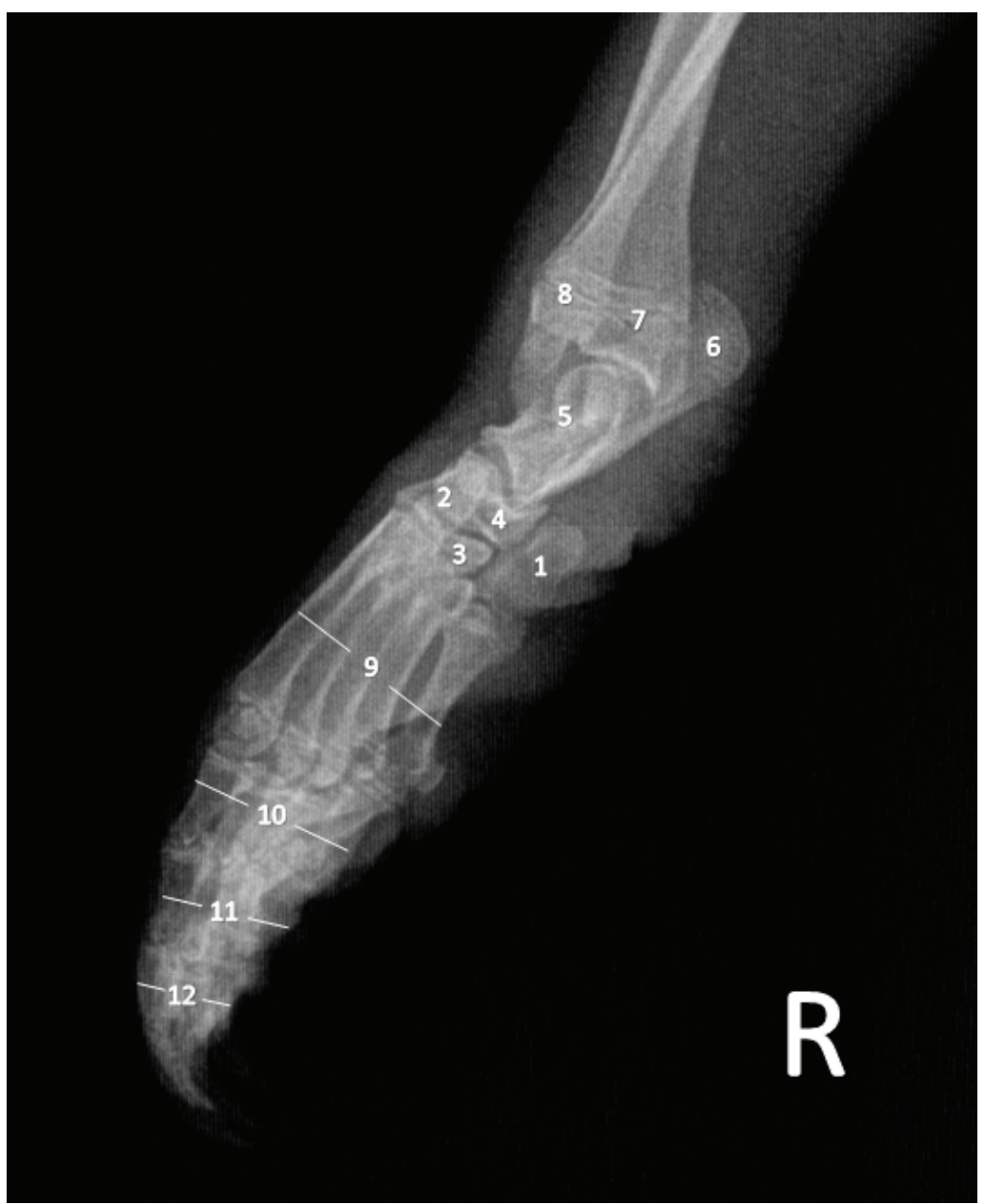

Figure 13. Radiographic view of the right tarsal, metatarsal bones, and phalanges of the T. mexicana. Mediolateral view: 1 - first tarsal bone, 2 - fourth tarsal bone, 3 - second and third tarsal bones, 4 - central tarsal bone, 5 - talus, 6 - calcaneal tuber, 7 -tibia, 8 - fibula, 9 - metacarpal bones, 10 - distal phalanges, 11 - middle phalanges, 12 - distal phalanges. Photograph by the authors.

\section{Discussion}

\section{Thoracic limb}

\section{Scapula}

The accessory scapular spine is reported for all Xenarthra (McDonald et al., 2008) and was also found in $T$. mexicana by Vélez-García and collaborators (2019). Behind the accessory scapular spine is a flat surface, called the caudolateral fossa, the origin site of the Teres major and subscapularis muscles. Also, a small portion of the subscapularis muscle and teres major muscle is inserted in the caudolateral fossa. The scapular head of the triceps 
muscle is attached to the accessory scapular spine, and the serratus magnus muscle attaches to the backside of the caudolateral fossa when seen from a medial view (Taylor, 1978; Nyakatura, 2011; Vélez-García, et al. 2019). The evolutionary development of the accessory scapular spine and caudolateral fossa is presumed to be a result of the need for greater force exertion for survival purposes such as looking for food or defending themselves, thus, the muscles that exert said force are the long head of the triceps brachii, teres minor and teres major muscles (VélezGarcía et al., 2019). When compared to other mammals, the presence of the caudolateral fossa in T. mexicana and Myrmecophaga tridactyla (Sesoko et al., 2015) differs from the Choloepus hoffmanni species (McDonald et al., 2008) and domestic animals such as the $C$. familiaris since none of them have this scapular component, even though the C. boffmanni also has a secondary scapular spine (Dyce et al., 2009; Liebich et al., 2020).

The presence of both accessory scapular spine and caudolateral fossa of the scapula may be a result of the need for a better muscle insertion to perform movements that require greater force and effort. Great examples of these actions are: climbing or destroying nests to collect termites (Taylor, 1978; Nyakatura, 2011; Rojano et al., 2014; Vélez-García, et al., 2019); Monteiro (2018) mentions that it has been reported that the shape of the scapula in a certain species is related to the function performed by the pelvic limb.

Within this study, it was found that the scapula has a "c" shaped supraglenoid notch, which means its periphery isn't completely delimited. This differs from the results found in T. mexicana by Vélez-García et.al (2019) who documented that the supraglenoid notch has a periphery completely delimited by bone and cartilage, but more research is needed to confirm this difference. Also, this supraglenoid notch is different from other species for which a complete supraglenoid foramen has been reported, as in the case of $M$. tridactyla and Bradypus variegatus (Sesoko et al., 2015; Freitas, 2018). Moreover, it is important to consider the possibility of cartilage loss due to overprocessing of the bone, this cartilage could be the one that completes the periphery of the supraglenoid foramen found by Vélez-García, et al 2019 (Rowley, 2015)

\section{Humerus}

The presence of a craniocaudally flattened distal epiphysis is a particularity of both $T$. mexicana and $M$. tridactyla species (Taylor, 1978; McDonald et al., 2008), this differs from the humeral structure present on other domestic mammals (Liebich et al., 2020) or species like B. variegatus (Freitas, 2018). This broadening of this humeral portion is due to a greater insertion area for the antebrachial extensor, flexor digitorum profundus, anconeus, and coracobrachialis muscles (Taylor, 1978). The tendon of the medial head of the triceps muscle, as well as the flexor digitorum profundus, attach to the third digit instead of attaching to the ulna like in other mammals this increases the force exertion at the time of digital flexion (Taylor, 1978; McDonald et al., 2015; Polania-Guzmán \& Vélez-García, 2019). The similarities between both mentioned anteaters may be due to a very similar ecology, including the type of habitat and behavior, which also explains the presence of the supratrochlear foramen on the two of them (Taylor, 1978; Sesoko et al., 2015); that characteristic is also found on the C. familiaris but not in other domestic mammals (Liebich et al., 2020).

\section{Radius}

The radius in T. mexicana, as in M. tridactyla (Sesoko et al., 2015), is thinner on its proximal end, and widens as it reaches the distal portion, where it is slightly flattened. Similar to domestic mammals, this species presents a styloid process, with the length as the only structural difference in T. mexicana and M. tridactyla (Liebich et al., 2020). 


\section{Ulna}

The structure of the ulna in the T. mexicana does not differ from those of domestic mammals (Liebich et al., 2020). Deep digital flexor muscles insert into this bone; they pass through the ulna and radius and insert at the base of the distal phalanges. The bracbioradialis and extensor carpi-radialis muscles are of great importance in elbow flexion, the first originates at the humerus and inserts around the forearm, the second originates from the lowest part of the deltoid tubercle (Toledo et al., 2015).

\section{Carpal and Metacarpal bones and phalanges}

Within this study it was found that the T. mexicana has eight carpal bones distributed in two rows which is consistent with the findings achieved by Lozada-Gallegos et al. (2020) on this species. Also, the number of carpal bones is shared with members of the same family, such as M. tridactyla (Sesoko et al., 2015) and Tamandua tetradactyla (Machado et al., 2018) who according to the authors also display, on their thoracic limbs, proximal and distal rows with their respective four carpal bones. Similarly, the carpal bones of $T$. mexicana coincide with the number of carpal bones found on domestic animals such as pigs, who also have a total of eight bones of this kind (Liebich et al., 2020). In addition, the sesamoid bone was also found by Lozada-Gallegos et al. (2020) on T. mexicana and was described by Polania-Guzmán and Vélez-García (2019) as a part of the flexor retinaculum, it was also mentioned that it articulates with the radial carpal bone on this species.

As previously mentioned, the third digit is the most prominent out of the five, though it is the biggest and strongest, it also has the least movement of all. The lack of movement could be due to the need for strength in order to increase the rotational force that allows this species to tear materials such as wood so as to achieve feed like termites, this being stated as the main evolutionary reason for these modifications at the level of thoracic limb. Since its diet consists of insects such as the latter, the T. mexicana, when hunting, approaches the nest with its limb fully extended, preventing ants and termites from attacking most of its body (Navarrete \& Ortega, 2011). These particularities are also shared with de $M$. tridactyla species (Sesoko et al., 2015). The shape and structural differences on the thoracic limbs of T. mexicana are related to its motion, feeding, and defensive behavior (Rojano et al., 2014), the modifications of the metacarpal bones and phalanges can be related to those reasons.

For self-defense, they use their claws instead of their jaw and teeth, since neither of those are strong enough to be considered as defense tools (Navarrete \& Ortega, 2011; Rojano et al., 2014). In their defense stance, they first flex their forearm by bringing the radius closer to the humerus, which subsequently retracts caudally and then upwards, this preparatory step allows them to throw a swipe against the predator in a gushing range of motion (Mora, 2000; Navarrete \& Ortega, 2011).

\section{Radiograpby}

Regarding the radiographic elaborated in figure 10, from this specific view, a series of structures can be distinguished. As Vélez-García et al. (2019) stated, a good amount of bone reliefs can be pointed at with ease when viewed from a mediolateral view, such as the scapular spine, which a prominence specifically designed for the insertion of the deltoid and trapezius muscles, can be seen mainly from a lateral view (Taylor, 1978; Vélez-García et al., 2019). Vélez-García et al. (2019) expressed that from a mediolateral point of view, the 
secondary scapular spine could be seen in a radiographic take; Arguedas et al. (2019) also took a radiography on this same view of a T. mexicana thoracic limb, and the accessory spine could be seen as well. However, on the radiographic take shown as figure 10, though the T. mexicana is on the same previously mentioned decubitus, the secondary spine isn't easily visible, this discrepancy is probably due to an angle difference that affected the x-ray incidence (Arguedas et al., 2019; Vélez-García et al., 2019).

In Vélez-García et al. (2019) radiography, a supraglenoid nerve foramen is distinguishable close to the humeral joint, this view is made possible due to its radiolucent peripheral outline. However, in figure 10 this foramen is seen from a slightly different angle, which makes it appear a more defined and sharper, but this could be due to various reasons such as technique used, radiographic system that was utilized, and animal size among other variables (Vélez-García et al., 2019).

As in Arguedas et al. (2019) and Vélez-García et al. (2019) thoracic limb radiographs, shows the coracoid process as well as the hamatus process of the acromion as radiolucent structures in their research. The coracoid process is where the coracobrachialis muscle originates; this muscle is the main protagonist of thoracic limb retraction and femoral head stabilization during said retraction motion (Matsuo et al., 2019).

Regarding carpal bones, the radiographic take showed that the joints in T. mexicana were both in the proximal and distal rows, as reported by Lozada-Gallegos et al. (2020). In addition to that, the same joints were also found in the $M$. tridactyla species (Sesoko et al., 2015). In the radiography it was also possible to observe how the digit $\mathrm{V}$ presents only one phalanx, which was reported by Lozada-Gallegos et al. (2020) for T. mexicana. In the same way, this characteristic was found by Machado et al. (2019) for T. tetradactyla; on the contrary, for $M$. tridactyla it has been reported that it presents a proximal phalanx as well as a distal one in the fifth digit (Sesoko et al., 2015).

\section{Pelvic limb}

\section{Femur}

The prominent greater trochanter and its position (distal from femoral head) suggest that this animal performs a greater range of movements, just like the Cyclopes didactylus species (Toledo et al., 2015). However, this is different from the $M$. tridactyla, whose range of motion is limited because it's fovea capitis is where the teres femoris ligament is inserted, this ligament creates tension when the limb is abducted. The shallow tibial tuberosity indicates the presence of a dense, yet short levered, quadriceps femoris which creates a powerful but slow limb motion for the limb. (Toledo et al., 2015).

The asymmetry between both distal epicondyles helps to stabilize the patellar movements. While the medial epicondyle contributes to rotational movements, the lateral epicondyle helps with the patella sliding into the patellar groove (Toledo et al., 2015).

\section{Tibia and fibula}

The slight bent disposition of this bone implies that it is further spaced from the fibula. With the presence of the flexor digitorum muscle, this structural disposition allows for force to be garnered for contracting the most distal part of the pelvic limb, the pes. At the distal part of this bone is localized a facet which allows 
the movement of the supinator-pronator, this facet is also found on Santacrucian sloths (Toledo et al., 2015).

As previously mentioned, the tibia of the T. mexicana species does not have a prominent tibial tuberosity, resulting in the absence of a tibial crest, unlike the $M$. tridactyla, which has a prominent tibial tuberosity and a well-defined tibial crest (Queiroz, 2012).

Unlike the Cingulata order from the Xenarthra superorder, the pelvic limbs from the Pilosa order do not only support the weight-bearing function but also aid in the movements used for locomotion, self-defense, and substrate extraction. These limbs, unlike the thoracic ones, are adapted for galloping (Toledo et al., 2015; Marshall et al., 2021).

\section{Tarsal, metatarsal bones and phalanges}

When comparing the talus and calcaneus bones of a $C$. familiaris individual to the same bone structures present on the T. mexicana pes, we can confirm that the identity of the bones that conform the proximal tarsal row are indeed the talus and calcaneus since the shape of said bones, in both species, is unmistakable and the homologous structures are alike to each other, also, both have the same laterality and articulate with the tibia (Liebich et al., 2020). Regarding the talus bone, in both species it is possible to distinguish the body from the trochlea of this bone structure, both are separated by a neck, the talus distally articulates with the central tarsal bone, and that is how the latter structure is identified on the radiographic take of the T. mexicana (Figure 13) since it is positioned the same way this bone would be on the C. familiaris species pes (Liebich et al., 2020). As for the calcaneus bone, Liebich et al. (2020) stated that it lays laterally to the talus bone, and it is also noted that a structure known as the calcaneal tuber is a protuberance that extends caudally, past the talus, which allows to recognize this bone structure as the calcaneus. The positioning of the different bones that conform the distal tarsal row can be appreciated on the radiographic takes that Liebich et al. (2020) did of the canine pes, the first, second, third and fourth tarsal bones can be seen, which allows to compare with other images (Figure 9 and 13) in order to identify these bones in various views of the same anatomical area.

The first tarsal bone (Figures 9 and 13) has an irregular outline and articulates on the medial aspect of the third and central tarsal bones, the third tarsal bone articulates with the second one and both lay below the central tarsal bone, these characteristics allow to identify said bone structures (Liebich et al., 2020). As for the fourth tarsal bone, is the only left to identify out of the total, it is easily seen from a lateral view of the pes, it proximally articulates with the calcaneus bone and medially with the third and second tarsal bones (Liebich et al., 2020).

In contrast to the thoracic limb digits, there is not a width difference found within the pes' metatarsal bones and phalanges, said difference isn't found on M. tridactyla or T. tetradactyla either (Rojano et al., 2014). The inconsistency between thoracic and pelvic limb digits' width could be due to T. mexicana mainly using their forepaws for climbing, hunting, and self-defense (Navarrete \& Ortega, 2011; Rojano et al., 2014).

\section{Radiography}

When comparing figure 12 to the lateral radiographic projection of the right pelvic limb taken by Arguedas et al. (2019) and Sesoko (2012), the same bone articular disposition is seen, which means that 
the femoral head is easily distinguishable and can be found articulated to the acetabular cavity, same with the greater trochanter.

The patella is also easy to find in figure 12 and both radiographs taken by Sesoko (2012) and Arguedas et al. (2019), since it is a very short and solid bone that faces outwards (Sesoko, 2012; Arguedas et al., 2019). The fibula looks like a small, long, and radiopaque bone that is obliquely positioned towards the tibia (Arguedas et al., 2019).

Lastly, in figure 12 and Arguedas et al. (2019) radiograph, the calcaneus bone can be seen as an elongated bone that articulates with the tibia with its tuberosity is partly overlapped by the medial malleolus bone (Arguedas et al., 2019).

\section{Morphometric measurements}

The difference in measurements between bilateral bones of one specimen was lesser than the difference found when comparing both lateralities between specimen A and B. In this instance, male anteater (individual A) bones are bigger than the female's (individual B). This difference could be due to sexual dimorphism on T. mexicana, such as the one found at craneal level, average length and length regarding tail and hind foot by Navarrete et al. (2017), this differs from what was found by other authors in the species T. tetradactyla, which does not present any kind of sexual dimorphism (Rossi, 2013; Rossi et al., 2013; de Souza \& Silva, 2016; Navarrete et al., 2017).

\section{Conclusion}

This study highlights the main particularities that are present in the appendicular bone structure of the T. mexicana, these distinctive characteristics remain mostly on the upper body, specifically at the level of thoracic limbs. The unique structures found mainly on the thoracic limbs are owed to adaptations developed overtime for efficient locomotion, hunting, and self-defense, the latter one carried by using its claws, which are also used to exert force. The previously mentioned actions take place by means of phalanges, metacarpus, humerus, and scapula. Due to this, it is required to have extensive, high-quality information and knowledge available about the anatomical bone structure of this species since it would be of great use in order to improve the clinical and surgical approach given to them, which is also needed to care for the wellbeing and perpetuation of the T. mexicana species. The radiographic knowledge of the appendicular system is imperative to achieve the capability of diagnosing and engaging with any procedure necessary in instances of pathologies, deformities, fractures, or others.

\section{Conflict of interest}

The authors have no conflict of interest.

\section{Acknowledgment}

The authors are grateful to Heiner Fabricio Serrano Alfaro, veterinary technician at the School of Veterinary Medicine (UNA) for his help regarding the preparation of the material used. To Dr. Adriana Camacho, 
imagenologist of HEMS, for her help with the radiographs taken. To Roy Alfaro Quesada, student at the School of Veterinary Medicine (UNA), for his collaboration in the dissection of the exemplars used. Last, but definitely not least, to Dr. Juan Fernando Vélez García, for the help he provided with his extensive knowledge about the T. mexicana species.

\section{References}

Aydin Kabakci, A. D., Buyukmumcu, M., Yilmaz, M. T., Cicekcibasi, A. E., Akin, D., \& Cihan, E. (2017). An Osteometric Study on Humerus. International Journal of Morphology, 35(1), 219-226. https://doi. org/10.4067/s0717-95022017000100036

Arguedas, R., López, E. C., \& Ovares, L. (2019). Bone fractures in roadkill Northern Tamandua Tamandua mexicana (Mammalia: Pilosa: Myrmecophagidae) in Costa Rica. Journal of Threatened Taxa, 11(14), 14802-14807. https://doi.org/10.11609/jott.4956.11.14.14802-14807

Brown, D. D. (2011). Fruit-Eating by an Obligate Insectivore: Palm Fruit Consumption in Wild Northern Tamanduas (Tamandua mexicana) in Panamá. Edentata, 12(1), 63-65. https://doi. org/10.5537/020.012.0110

Burton, A. M., \& González, G. C. (2006). Northern-most record of the collared anteater (Tamandua mexicana) from the Pacific slope of Mexico. Revista Mexicana de Mastozoología, 10(1), 67-70. https:// doi.org/10.22201/ie.20074484e.2006.10.1.142

de Souza Hossotani, C. M., \& Helder Silva, L. (2016). Aspectos reprodutivos do Tamanduá-mirim (Tamandua tetradactyla Linnaeus, 1758). Revista Brasileira de Reprodução Animal, 40(3), 95-98. http://www.cbra.org.br/portal/downloads/publicacoes/rbra/v40/n3/p095-98\%20(RB619).pdf

Dyce, K. M., Sack, W. O., \& Wensing, C. J. G. (2009). Textbook of Veterinary Anatomy (4th ed.). Saunders.

Esser, H., Brown, D. \& Liefting, Y. (2010). Swimming in the Northern Tamandua (Tamandua mexicana) in Panama, Edentata, 11, 70-72. https://doi.org/10.1896/020.011.0112

Sesoko, F.N. (2012). Estudo anatômico e imagiológico do braço e da coxa em tamanduá-bandeira (Myrmecophaga tridactyla - linnaeus, 1758) para a determinação de acesso cirúrgico [Tesis de maestría, Universidad Estadual Paulista]. https://repositorio.unesp.br/bitstream/handle/11449/99858/000696048. pdf? sequence $=1 \&$ is Allowed $=y$

Sesoko, F.N., Rahal, S.C., Bortolini, Z., De Souza, L.P., Vulcano, L.C., Barros, F.O. \& Teixeira, C.R. (2015). Skeletal morphology of the forelimb of Myrmecophaga Tridactyla. Journal of Zoo and Wildlife Medicine, 46(4), 713-722. https://doi.org/10.1638/2013-0102.1

Freitas, K. (2018). Estudo das variaçôes anátomo-radiográficas do esqueleto do bicho-preguiça-de-gargantamarrom (Bradypus variegatus, Schinz, 1825) [Tesis de Licenciatura, Universidad Federal da Paraíba]. https://repositorio.ufpb.br/jspui/handle/123456789/12608

Göker, P., Bozkır, M. G., Yücel, A. H. \& Ozandac S. (2015). An Osteometric Study of proximal and distal femur Morphology. Cukurova Medicine, 40(3), 466-473. https://doi.org/10.17826/cutf.82812 
Liebich, H.G., Maierl, J., \& König, H.E. (2020). Veterinary Anatomy of Domestic Mammals: Textbook and Colour Atlas. Thieme.

Lozada-Gallegos, R.A., Muñoz-García, I.C., Ovando-Fuentes, D., Rendón-Franco, E., Reyes-Delgado, F., Rocha-Martínez, N., Trejos-Salas, B.M \& Villanueva-García C. (2020). Radiographic anatomy of the forelimb in the northern tamandua (Tamandua mexicana). Journal of Zoo and Wildlife Medicine. 51(2),265-274. https://doi.org/10.1638/2018-0047

Marshall, S. K., Spainhower, K. B., Sinn, B. T., Diggins, T. P., \& Butcher, M. T. (2021). Hind Limb Bone Proportions Reveal Unexpected Morphofunctional Diversification in Xenarthrans. Journal of Mammalian Evolution, 28(3), 599-619. https://doi.org/10.1007/s10914-021-09537-w

Matsuo, T., Morita, F., Tani, D., Nakamura, H., Higurashi, Y., Ohgi, J., Luziga, C. \& Wada, N. (2019). Anatomical variation of habitat-related changes in scapular morphology. Anatomia, Histologia, Embryologia, 48(3), 218-227. https://doi.org/10.1111/ahe.12426

McDonald, H.G., Vizcaíno, S.F. \& Bargo, M.S. (2008). Skeletal anatomy and the fossil history of the Vermilingua. In: Vizcaíno, S. F. \& Loughry, W. J. (Eds.), The Biology of the Xenarthra (1 ed., pp. 64-78). University Press of Florida.

Monteiro, L.R. \& Abe, A.S. (1999). Functional and historical determinants of shape in the scapula of Xenarthran mammals: Evolution of a complex morphological structure. Journal of Morphology 241, 251-263. $\quad$ https://doi.org/10.1111/ahe.12426:10.1002/(SICI)1097-4687(199909)241:3<251::AIDIMOR7>3.0.CO;2-7

Mora, J.M. (2000). Mamiferossilvestres de Costa Rica. EUNED. https://books.google.co.cr/books? id=4IITb 9RrSFcC\&pg=PA53\&dq=tamandua + mexicana\&hl=es\&sa=X\&ved=2ahUKEwiQ3-6frZjqAhUxnAKHdTVAOIQ6AEwAHoECAEQAg\# $\mathrm{v}=$ onepage\&q=tamandua\%20mexicana\&f=false.

Navarrete, D. \& Ortega, J.D. (2011). Tamandua mexicana (Pilosa;Myrmecophagidae). Mammalian Species 43(874), 56-63. https://doi.org/10.1644/874.1

Nyakatura, J. A. (2011). The Convergent Evolution of Suspensory Posture and Locomotion in Tree Sloths. Journal of Mammalian Evolution, 19(3), 225-234. https://doi.org/10.1007/s10914-011-9174-X

Polania-Guzmán, P. V., \& Vélez-García, J. F. (2019). Gross anatomical adaptations of the craniolateral forearm muscles in Tamandua mexicana (Xenarthra: Myrmecophagidae): development of accessory muscles and rete mirabile for its arterial supply. Heliyon, 5(8), e02179. https://doi.org/10.1016/j. heliyon.2019.e02179

Queiroz, R.P. (2012). Anatomia Óssea, Muscular E Do Movimento Das Regióes Glútea E Coxa Do Tamanduá Bandeira Myrmecophaga Tridactyla (Myrmecophagidae: Pilosa) [Tesis de Maestría, Universidad Federal de Uberlândia]. https://repositorio.ufu.br/bitstream/123456789/13027/1/d.pdf

Rojano, C., Miranda, L.M. \& Ávila, R.C. (2014). Manual de Rebabilitación de Hormigueros de Colombia. Colombia: Geopark Colombia. [Archivo PDF]. https://www.researchgate. net/publication/287193942_Manual_de_Rehabilitacion_de_Hormigueros_de Colombia\#fullTextFileContent 
Rossi, L.F. (2013). Citogenética y biologia de la reproducción en Myrmecophagidae (Xenarthra) de Argentina [Tesis Doctoral, Universidad de Buenos Aires]. http://hdl.handle.net/20.500.12110/tesis_n5301_Rossi

Rossi, L.F, Calderón, R., Alonso, F.M., Lueces, J.P., Merani, M.S. (2013). Observaciones anatómicas e histológicas del sistema reproductor masculino y femenino en Tamandua tetradactyla(Myrmecophagidae: Xenarthra). InVet, 15(1), 17-28. https://core.ac.uk/download/pdf/148102746.pdf

Rowley, B. (2015). Protocols for cleaning and articulating large mammal skeleton: Simposium Student Journal of Science \& Math 2 (1), 1-27. https://digitalcommons.calpoly.edu/symposium/vol2/iss1/3/

Sandoval-Gómez, V.E., Ramírez-Chaves, H.E. \& Marín, D. (2012). Registros de Hormigas Y Termitas Presentes en la Dieta de Osos Hormigueros (Mammalia: Myrmecophagidae) en Tres Localidades de Colombia. Edentata, 13(11), 1-9. https://doi.org/10.5537/020.013.0104

Superina, M., Miranda, F.R. \& Abba, A.M. (2010). The 2010 Anteater Red List Assessment. Edentata, 11(12), 96-114. https://doi.org/10.5537/020.011.0201

Taylor, B.K. 1978. The anatomy of the forelimb in the anteater (Tamandua) and its functional implications. Journal of Morphology, 157(3), 347-367. https://doi.org/10.1002/jmor.1051570307

Toledo, N., Bargo, M.S. \& Vizcaíno, S.F. (2015). Muscular reconstruction and functional morphology of the hindlimb of santacrucian (Early Miocene) sloths (Xenarthra, Folivora) of Patagonia. The Anatomical Record, 298(5), 842-864. https://doi.org/10.1002/ar.23114

Vélez-García, J.F., Torres-Suárez, S.V. \& Echeverry-Bonilla, D. F. (2019). Anatomical and radiographic study of the scapula in juveniles and adults of Tamandua mexicana (Xenarthra: Myrmecophagidae). Anatomia, Histologia, Embryologia, 49(2), 203-215. https://doi.org/10.1111/ahe.12514 